\title{
ESG 2015 vs. ISO 9001:2015 Regarding Stakeholders
}

\author{
Rasha Alkabbanie ${ }^{1}$ \\ ${ }^{1}$ Mechatronics Engineering Department, Faculty of Engineering, Tishk International University, Erbil, \\ Iraq \\ Correspondence: Rasha Alkabbanie, Tishk International University, Erbil, Iraq. \\ Email: rasha.alkabbanie@tiu.edu.iq
}

Doi: 10.23918/ijsses.v7i2p46

\begin{abstract}
Recently, the higher education institutions have been facing an intense competition and internationalization challenges. Thus, a need for adopting a solid and integrated management system has arisen. Universities adopting the European Higher Education System and/or applying Bologna Process in their academic programs shall ensure the compatibility of their educational systems with the standards and the guidelines of ESG (The Standards and Guidelines for Quality Assurance in the European Higher Education Area). On the other hand, some higher education institutions design their Quality Management Systems according to international standards such as ISO 9001 in order to ensure the improvement in their competitive position, to have a better systemization, and to increase the effectiveness of their processes. This paper compares between ISO 9001:2015 and ESG 2015 regarding the involvement of stakeholders in the quality process of the academic institutions. The study showed that the standard ISO 9001 is much more comprehensive and detailed than the ESG 2015.
\end{abstract}

Keywords: ISO 9001, ESG 2015, Stakeholders, Quality Management, Quality Assurance

\section{Introduction}

The quality at higher education institution refers to the case where the educational process outcomes conform to the mission and vision or to the standards adopted by the institution. As the universities are accountable to stakeholders for the best utilization of the resources and to providing the superior educational services, also the stakeholders are considering as contributors in improving the quality in the academic institution (Nicholson, 2011). Quality assurance is one of the fields that the stakeholders are encouraged to contribute to (Ulewicz, 2017). Labanavskis and Ginericivs (2017) found that stakeholders are considered as an important source of information that supports the growth and the progress of the universities. And the involvement of the stakeholders in the university's process is a powerful factor in defining the development roadmap of the higher education institution. The study of Loisyte and Westerheijden (2014) showed that the importance of the role of the stakeholders differs from a country to another and across the types of the stakeholders.

In European countries, the involvement of the stakeholders in the university's governance became a condition for development. The study by Beerkens and Udam (2017) revealed that engaging stakeholders in preparing the university's policies would lead to a more commitment and seriousness. According to ESG 2015, the term "Stockholders" refers to all the actors within the educational system such as the students, staff, employers and partners.

In ISO 9001 Standard, stakeholders are refereed to synonymously as Interested Parties. In this standard, the term "Interested Party" refers to any individual or organization that: 
- Has a possible impact on the quality and decisions of the institution

- Has an ability to cause a risk/opportunity in the institution

- Can affect the market

- Can be impacted by the institution's decisions

- Is expected to be affected by any process, policy, product, service, decision or action done by the institution.

ISO 9001 Standard focuses on the interested parties (stakeholders) basically in clauses 4.2. Also, clauses number (5.2.2), (8.2.2), and (9.3.1). In this paper, clause (4.2) will be discussed in details while the other clauses will be explored briefly. In the ESG 2015, the guidelines related to the stakeholders are stated in the clauses (1.1), (1.2), (1.8), and (1.9). Those will be also discussed in the paper in comparative with the ISO 9001 Standard practices.

\subsection{ISO 9001}

This international standard is designed for the quality management system and it proceeds from the following principles:

- Customer focus,

- Leadership,

- Involving staff,

- Procedure methodology,

- Enhancement,

- Making decisions based on evidence,

- Coordinating relations (Fonseca, 2015).

Studies illustrated that implementing the quality management system according to SIO 9001 will change the foundation's performance for the better (Powell, 1995). By adopting ISO 9001 system, more value will be given to the customers and the efficiency of the processes will be upgraded (Tarí et al., 2012). The 2015 version of the standard provides more benefits as for the risk-based thinking, stakeholders' specification, and determination of the organization context (Fonseca \& Domingues, 2018).

\subsection{ESG 2015}

ESG 2015 represents the European Higher Education Area's standards and guidelines for Quality Assurance. Those standards have been followed by the Ministers in charge of the higher education in the European Higher Education area in May 2015 (ESG 2015).

\section{Stakeholders in ISO 9001:2015 Standard}

\subsection{Regarding Clause 4.2/ISO 9001:2015}

This chapter states that the organization shall:

- Specify the interested parties which are affecting/affected by the quality management system

- Determine the requirements of those interested parties pertinent to the quality management system 
- Review the list of the interested parties and their needs on a regular basis

By implementing this clause, the organization manages the impacts (positive/negative) of the stakeholders in an effective way. Determining the stakeholders of the institution is a very essential part in implementing the ISO 9001 Standard. Because they are, together with the Context of the Organization, form the Scope of the Management System. So, they should be determined prior to defining the Scope. According to the standard, the interested parties can be determined after understanding the organization and its context (clause 4.1 of the Standard).

The standard indicates that the organization shall determine the context of the external and internal issues related to its strategy and objectives. This can be done by many methods. At TIU (Tishk International University-Erbil), the Context of the Management System was defined through the following methods:

- Porter's Five Forces.

- The PEST Analysis.

- The SWOT Analysis.

These methods helped to define the List of Interested Parties of TIU are indicated in the table below.

Table 1: Methods helped to define the List of Interested Parties

\begin{tabular}{|l|l|}
\hline The Method & Brief Definition of the Method \\
\hline Porter's Five Forces & $\begin{array}{l}\text { A method that attempts to analyze the competitiveness situation } \\
\text { of the institution. }\end{array}$ \\
\hline PEST Analysis & $\begin{array}{l}\text { A framework that defines the macro-environmental factors that } \\
\text { affect the quality management (political factors - economic } \\
\text { factors - socio/cultural factors - technological factors). }\end{array}$ \\
\hline SWOT Analysis & $\begin{array}{l}\text { A method that further determines the external and internal issues } \\
\text { that affect the quality system of the institution. }\end{array}$ \\
\hline
\end{tabular}

Source: The Author

The Quality Management experts recommend categorizing the interested parties to groups according to their impacts. For example, they can be grouped into the following groups: Responsibility- related stakeholders, Influencers, Vicinity stakeholders, Depended- on stakeholders, Evaluators, Authorities, Customers, Suppliers, and Partners. 


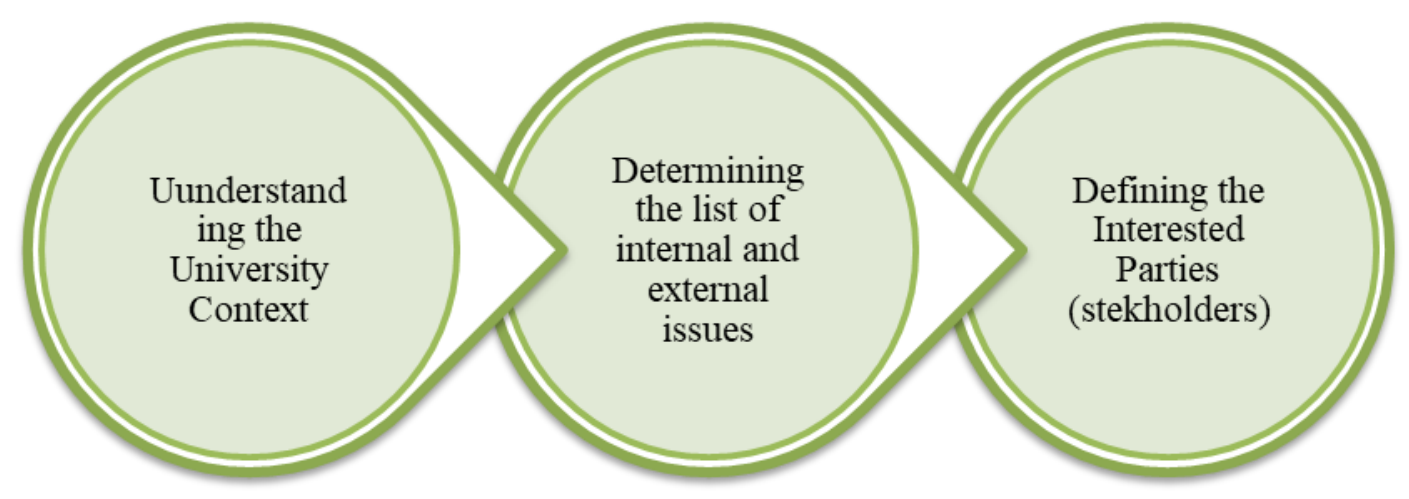

Figure 1: The steps sequence of determining the stakeholders according to ISO 9001:2015

Source: The Author

According to the standard, the needs and the expectations of the interested parties shall be addressed. This has been done at TIU as per Table (2). According to their needs/requirements, the interested parties can be plotted using the Power/Interest Matrix. Mapping the stakeholders using this tool depends on how much power do they make over the decision of the institution and on how much interest do they have in the institution's procedures.

\subsection{Regarding Clause 4.5.2.2/ISO 9001:2015}

This clause states that the Quality Policies of the institution shall be communicated to the interested parties. At TIU, the Quality Policies are uploaded to the University website so everybody can reach it. Additionally, when the Policy is modified, the interested parties are notified through emails, letters, meetings ...etc.

\subsection{Regarding Clause 8.2.2/ISO 9001:2015}

This clause indicates that the institution has to establish special processes to check whether the needs and the requirements of the interested parties are fulfilled or not. At TIU, the processes/methods used for ensuring the fulfilment of the stakeholders' requirements are listed in Table (2).

Table 2: Stakeholders (interested parties) table at TIU

\begin{tabular}{|l|l|l|l|}
\hline $\begin{array}{l}\text { The } \\
\text { Stakeholders } \\
\text { (Interested } \\
\text { Parties) }\end{array}$ & $\begin{array}{l}\text { Reasons for } \\
\text { Inclusion }\end{array}$ & $\begin{array}{l}\text { Requirements and } \\
\text { Expectations } \\
\text { (Issues of Concern) }\end{array}$ & Evaluation Methods \\
\hline $\begin{array}{l}\text { ISO Certifying } \\
\text { body }\end{array}$ & $\begin{array}{l}\text { Performs auditing } \\
\text { for ISO } \\
\text { Compliance and } \\
\text { ISSUE Certificate }\end{array}$ & $\begin{array}{l}\text { Good level of } \\
\text { compliance of the } \\
\text { university to the ISO } \\
\text { standard. }\end{array}$ & Internal Auditing \\
\hline
\end{tabular}




\begin{tabular}{|c|c|c|c|}
\hline $\begin{array}{l}\text { The } \\
\text { Stakeholders } \\
\text { (Interested } \\
\text { Parties) }\end{array}$ & $\begin{array}{l}\text { Reasons for } \\
\text { Inclusion }\end{array}$ & $\begin{array}{l}\text { Requirements and } \\
\text { Expectations } \\
\text { (Issues of Concern) }\end{array}$ & Evaluation Methods \\
\hline $\begin{array}{l}\text { Board of } \\
\text { Trustees }\end{array}$ & $\begin{array}{l}\text { This board is } \\
\text { responsible about } \\
\text { issuing the } \\
\text { policies, mission, } \\
\text { and Vision of the } \\
\text { university and } \\
\text { approving the } \\
\text { Strategic Plan }\end{array}$ & $\begin{array}{l}\text { Good financial } \\
\text { performance, } \\
\text { legal compliance } \\
\text { avoidance of fines }\end{array}$ & $\begin{array}{l}\text { Strategic plan } \\
\text { evaluation }\end{array}$ \\
\hline $\begin{array}{l}\text { University } \\
\text { Council }\end{array}$ & $\begin{array}{l}\text { Provide the } \\
\text { leadership and } \\
\text { resources }\end{array}$ & $\begin{array}{l}\text { the academic processes } \\
\text { to be performed at a } \\
\text { quality level } \\
\text { the services provided in } \\
\text { the university to fulfill } \\
\text { the requirements of the } \\
\text { students and staff }\end{array}$ & $\begin{array}{l}\text { Management review } \\
\text { Students satisfaction } \\
\text { survey results }\end{array}$ \\
\hline $\begin{array}{l}\text { Heads of } \\
\text { Departments } \\
\text { and Directors of } \\
\text { Units }\end{array}$ & $\begin{array}{l}\text { Provide leadership } \\
\text { to the departments } \\
\text { and units }\end{array}$ & $\begin{array}{l}\text { The students to get a } \\
\text { high education level } \\
\text { The academic } \\
\text { performance of the staff } \\
\text { to be developed } \\
\text { Expect to be well } \\
\text { compensated } \\
\text { Expect a good work } \\
\text { atmosphere }\end{array}$ & $\begin{array}{l}\text { Students satisfaction } \\
\text { survey results } \\
\text { Lecturers satisfaction } \\
\text { about the Head of } \\
\text { Department } \\
\text { Good preparations } \\
\text { for the budget }\end{array}$ \\
\hline Academic Staff & $\begin{array}{l}\text { Providing } \\
\text { educational } \\
\text { services }\end{array}$ & $\begin{array}{l}\text { Academic development } \\
\text { through internal and } \\
\text { external seminars and } \\
\text { workshops } \\
\text { prompt payment } \\
\text { financial support for the } \\
\text { research activities } \\
\text { fair promotion system } \\
\text { healthy and safe work } \\
\text { environment } \\
\text { work/ life balance }\end{array}$ & $\begin{array}{l}\text { applying questioners } \\
\text { and surveys } \\
\text { reimbursement } \\
\text { requests } \\
\text { quality assurance } \\
\text { process } \\
\text { department meetings } \\
\text { petition letters }\end{array}$ \\
\hline
\end{tabular}




\begin{tabular}{|c|c|c|c|}
\hline $\begin{array}{l}\text { The } \\
\text { Stakeholders } \\
\text { (Interested } \\
\text { Parties) }\end{array}$ & $\begin{array}{l}\text { Reasons for } \\
\text { Inclusion }\end{array}$ & $\begin{array}{l}\text { Requirements and } \\
\text { Expectations } \\
\text { (Issues of Concern) }\end{array}$ & Evaluation Methods \\
\hline $\begin{array}{l}\text { Administrative } \\
\text { Staff }\end{array}$ & $\begin{array}{l}\text { Providing } \\
\text { administrational } \\
\text { services }\end{array}$ & $\begin{array}{l}\text { Professional } \\
\text { development through } \\
\text { courses and workshops } \\
\text { prompt payment } \\
\text { fair position-upgrading } \\
\text { system } \\
\text { healthy and safe work } \\
\text { environment } \\
\text { work/ life balance } \\
\text { good reference }\end{array}$ & $\begin{array}{l}\text { applying questioners } \\
\text { and surveys } \\
\text { unit meetings } \\
\text { petition letters }\end{array}$ \\
\hline Students & $\begin{array}{l}\text { They receive the } \\
\text { services }\end{array}$ & $\begin{array}{l}\text { high-quality education } \\
\text { international curriculum } \\
\text { quick response to their } \\
\text { needs } \\
\text { quick response to their } \\
\text { problems } \\
\text { fair assessment methods } \\
\text { and application } \\
\text { good post-graduating } \\
\text { services } \\
\text { high quality educational } \\
\text { and administrative } \\
\text { services within the } \\
\text { universities }\end{array}$ & $\begin{array}{l}\text { applying a lot of } \\
\text { questioners and } \\
\text { surveys } \\
\text { through classroom } \\
\text { representatives and } \\
\text { students counsel } \\
\text { inviting students } \\
\text { representatives to } \\
\text { department - faculty } \\
\text { and university boards } \\
\text { meetings (when } \\
\text { needed) } \\
\text { petition letters } \\
\text { academic advising } \\
\text { system }\end{array}$ \\
\hline Government & $\begin{array}{l}\text { Mandate regulatory } \\
\text { requirements }\end{array}$ & $\begin{array}{l}\text { responding to all the } \\
\text { statutory and regulatory } \\
\text { requirements related to } \\
\text { private universities in the } \\
\text { region } \\
\text { applying the related } \\
\text { decisions }\end{array}$ & NUR System \\
\hline Community & $\begin{array}{l}\text { Affected by the } \\
\text { activities of the } \\
\text { university }\end{array}$ & $\begin{array}{l}\text { No complaints relating } \\
\text { to: noise, parking, health } \\
\text { and safety, pollution, } \\
\text { waste, employment }\end{array}$ & $\begin{array}{l}\text { complaints form } \\
\text { Through the social } \\
\text { activities of the } \\
\text { "dean of students" } \\
\text { unit. }\end{array}$ \\
\hline
\end{tabular}




\begin{tabular}{|c|c|c|c|}
\hline $\begin{array}{l}\text { The } \\
\text { Stakeholders } \\
\text { (Interested } \\
\text { Parties) }\end{array}$ & $\begin{array}{l}\text { Reasons for } \\
\text { Inclusion }\end{array}$ & $\begin{array}{l}\text { Requirements and } \\
\text { Expectations } \\
\text { (Issues of Concern) }\end{array}$ & Evaluation Methods \\
\hline $\begin{array}{l}\text { External } \\
\text { Providers of } \\
\text { Services }\end{array}$ & $\begin{array}{l}\text { Provide some } \\
\text { service for the } \\
\text { university }\end{array}$ & $\begin{array}{l}\text { Prompt payment } \\
\text { healthy and safe work } \\
\text { environment } \\
\text { good work relationship }\end{array}$ & $\begin{array}{l}\text { petition/complaints } \\
\text { letters }\end{array}$ \\
\hline Suppliers & $\begin{array}{l}\text { Provide material } \\
\text { and services }\end{array}$ & $\begin{array}{l}\text { Prompt payment } \\
\text { Requires clearly } \\
\text { specifications of the } \\
\text { products }\end{array}$ & $\begin{array}{l}\text { Appropriate } \\
\text { implication of the } \\
\text { purchasing process }\end{array}$ \\
\hline $\begin{array}{l}\text { Partners } \\
\text { International } \\
\text { HEIs }\end{array}$ & $\begin{array}{l}\text { Partners in the } \\
\text { MOUs }\end{array}$ & $\begin{array}{l}\text { Fully complying the } \\
\text { articles in the MOUs }\end{array}$ & $\begin{array}{l}\text { Average period of } \\
\text { MOUs retaining }\end{array}$ \\
\hline $\begin{array}{l}\text { Accreditation } \\
\text { Services }\end{array}$ & $\begin{array}{l}\text { Providing program } \\
\text { and institutional } \\
\text { international } \\
\text { accreditation } \\
\text { review and } \\
\text { certifying services }\end{array}$ & $\begin{array}{l}\text { Good level of } \\
\text { compliance of the } \\
\text { university to the } \\
\text { European Standers }\end{array}$ & The audit results \\
\hline
\end{tabular}

Source: The Author

\subsection{Regarding Clause 9.3.1/ISO 9001:2015}

This clause states that the institution shall review and discuss the fulfilment of the interested parties' requirements in the Management Review Meeting (which should be held twice a year at least).

\section{Stakeholders in ESG 2015 Guidelines}

\subsection{Regarding Clause 1.1/ESG 2015}

This clause indicates that the internal stakeholders shall contribute to developing and implementing the quality assurance policy of the institution. This clause is served by the ISO 9001:2015 Quality Management System through the concept of "Process Owner". Process owner in ISO 9001 is the staff who has the responsibility and the authority for controlling a certain process. And according to 4.2.b/ISO 9001:2015, the requirements of the interested parties shall be determined and the fulfilment of these needs shall be checked through special processes/methods.

TIU assigned the Chair of the Quality Assurance Committee to be the Process Owner of the Quality Assurance Policy. This Committee is composed of representatives of the University Management, representatives of the teaching body, representative of the students' body, and others. The draft policy is prepared by the Chair in consultation with the Committee Members. 


\subsection{Regarding Clause 1.2/ESG 2015}

This clause states that the stakeholders (especially students) shall be involved in designing the study programs. The same clauses of ISO 9001:2015 mentioned in the previous paragraph are also applicable for this point.

At TIU, the Quality Management System procedures related to designing and reviewing the curriculum of the study programs states that:

- The owner of the process is the Head of the Program Scientific Committee (this committee is composed of the full-time academic staff of the program).

- The University Council (representing the University's Top Management) shall ensure that all the resources needed for this procedure are provided.

- Representatives of the students, the alumni, and the employers shall join the curriculum design and review meetings and to contribute in developing the final version of the curriculum and the program content.

- The same applies to "Designing and Updating the Program Learning Outcomes".

\subsection{Regarding Clause 1.8/ESG 2015}

This clause indicates that the institution shall assure each of the Quality Policy, the Responsibilities, and Authorities, and the Quality Objectives of the institution are communicated to the internal stakeholders.

This clause is served by the ISO 9001:2015 Standard through the following ISO clauses:

- In clause 7.4/ISO 9001:2015, the institution shall define the internal and the external communications and how, what, when, and with whom to communicate.

- In clause 8.2/ISO 9001:2015, the information related to the institution processes shall be communicated to the customers (students).

- In clause 8.4.3/ISO 9001:2015, the institution shall communicate the information related to the processes to the external providers (additionally to the competences of the personnel and the evaluation output of the suppliers.

\subsection{Regarding Clause 1.9/ESG 2015}

This clause states that the institution should provide information about the activities to the stakeholders.

This clause is served by ISO 9001:2015 through clause 9.3.1 which indicates that the institution shall hold Management Review Meetings periodically (once a year at least). This meeting is held by the Top Management of the institution additionally to representatives of almost all the stakeholders. The following points should be discussed in details in this important meeting and decisions shall be made according to the outputs;

- The quality policies

- The quality objectives

- The outcomes of the quality audits and controls 
- The annual achievement of the quality objectives

- The outcome of the Risk Assessment Process

- The new regulations and policies

- The performance of the external providers

As it is shown, the meeting members (including representatives of the stakeholders) are informed about this key information and they have an essential role in decisions making.

\section{The Findings}

The sections of the article allow us to make a comprehensive comparison between ESG 2015 and ISO 9001:2015 regarding stakeholders' involvement in the quality process.

Table 3: ISO 9001:2015 vs. ESG 2015 Regarding Stakeholders' Involvement

\begin{tabular}{|l|l|l|}
\hline The Points & ISO 9001:2015 & ESG 2015 \\
\hline $\begin{array}{l}\text { Determining the } \\
\text { stakeholders according to } \\
\text { the context of the institution }\end{array}$ & $\begin{array}{l}\text { Applied } \\
\text { (chapter 4.2/ISO 9001:2015) }\end{array}$ & Not applied \\
\hline $\begin{array}{l}\text { Determining the } \\
\text { requirements/needs of the } \\
\text { stakeholders }\end{array}$ & $\begin{array}{l}\text { Applied } \\
\text { (chapter 4.2/ISO 9001:2015) }\end{array}$ & Not applied \\
\hline $\begin{array}{l}\text { Establishing processes for } \\
\text { checking the fulfilment of } \\
\text { the stakeholders } \\
\text { requirements }\end{array}$ & $\begin{array}{l}\text { Applied } \\
\text { (chapter 8.2.2/ISO } \\
9001: 2015)\end{array}$ & Not applied \\
\hline $\begin{array}{l}\text { The Quality Policies of the } \\
\text { institution shall be } \\
\text { communicated to the } \\
\text { stakeholders }\end{array}$ & $\begin{array}{l}\text { Applied } \\
\text { (chapter 4.5.2.2/ISO }\end{array}$ & $\begin{array}{l}\text { Applied } \\
\text { (chapter 1.1/ESG 2015) }\end{array}$ \\
\hline $\begin{array}{l}\text { The institution shall review } \\
\text { and discuss the fulfilment of } \\
\text { the interested parties' } \\
\text { requirements }\end{array}$ & $\begin{array}{l}\text { Applied } \\
\text { (chapter 9.3.1/ISO } \\
\text { 9001:2015) }\end{array}$ & $\begin{array}{l}\text { Applied } \\
\text { (chapter 1.2/ESG 2015) }\end{array}$ \\
\hline $\begin{array}{l}\text { The internal stakeholders } \\
\text { shall contribute to } \\
\text { developing and } \\
\text { implementing the quality } \\
\text { assurance policy of the } \\
\text { institution }\end{array}$ & $\begin{array}{l}\text { Applied } \\
\text { (chapter 4.2/ISO 9001:2015) }\end{array}$ & $\begin{array}{l}\text { Applied } \\
\text { (chapter 1.1/ESG 2015) }\end{array}$ \\
\hline $\begin{array}{l}\text { The stakeholders (especially } \\
\text { students) shall be involved } \\
\text { in designing the study } \\
\text { programs. }\end{array}$ & (chapter 4.2/ISO 9001:2015) & Notied \\
\hline
\end{tabular}




\begin{tabular}{|l|l|l|}
\hline $\begin{array}{l}\text { The institution shall assure } \\
\text { each of the Quality Policy, } \\
\text { the Responsibilities and } \\
\begin{array}{l}\text { Authorities, and the Quality } \\
\text { Objectives of The institution } \\
\text { are communicated to the } \\
\text { internal stakeholders }\end{array}\end{array}$ & $\begin{array}{l}\text { Applied } \\
\text { (chapter 7.4 \& 8.2 \& } \\
8.4 .3 / \text { ISO 9001:2015) }\end{array}$ & $\begin{array}{l}\text { Applied } \\
\text { (chapter 1.8/ESG 2015) }\end{array}$ \\
\hline $\begin{array}{l}\text { The institution should } \\
\text { provide information about } \\
\text { the activities to the } \\
\text { stakeholders }\end{array}$ & $\begin{array}{l}\text { Applied } \\
\text { (chapter 9.3.1/ISO } \\
9001: 2015)\end{array}$ & $\begin{array}{l}\text { Applied } \\
\text { (chapter 1.9/ESG 2015) }\end{array}$ \\
\hline
\end{tabular}

Source: The Author

\section{Conclusion}

This study showed that the standard ISO 9001 is much more comprehensive and detailed than the ESG 2015 regarding the stakeholders.

The ESG shall include guidelines about the followings:

- Determining the stakeholders according to the context of the institution

- Determining the requirements/needs of the stakeholders

- Establishing processes for checking the fulfilment of the stakeholders' requirements

\section{References}

Beerkens, M., \& Udam, M. (2017). Stakeholders in higher education quality assurance: Richness in diversity? Higher Education Policy, 30(3), 341-359.

European Association for Quality Assurance in Higher Education (ENQA). (2015). Standards and guidelines for quality assurance in the European Higher Education Area (ESG).

Fonseca, L. (2015). From Quality Gurus and TQM to ISO 9001: 2015: a review of several quality paths. International Journal for Quality Research (IJQR), 9(1), 167-180.

Fonseca, L. M., \& Domingues, J. P. (2018). Empirical research of the ISO 9001: 2015 transition process in Portugal: Motivations, benefits, and success factors. Quality Innovation Prosperity, 22(2), 16-46.

International Organization for Standardization. (2015). Quality management systems - Requirements with guidance for use (ISO Standard No. 9001).

Labanauskis, R., \& Ginevičius, R. (2017). Role of stakeholders leading to development of higher education services. Engineering Management in Production and Services, 9(3), 63-75.

Leisyte, L., \& Westerheijden, D. F. (2014). Stakeholders and quality assurance in higher education. In Drivers and barriers to achieving quality in higher education (pp. 83-97). Brill Sense.

Nicholson, K. (2011). Quality assurance in higher education: A review of the literature. Retrieved from http://cll.mcmaster.ca/.

Powell, T.C. (1995). Total quality management as competitive advantage: A review and empirical study. Strategic Management Journal, 16, 15-37. 
Tarí, J. J., Molina-Azorín, J. F., \& Heras, I. (2012). Benefits of the ISO 9001 and ISO 14001 standards: A literature review. Journal of Industrial Engineering and Management (JIEM), 5(2), 297 322.

Ulewicz, R. (2017). The role of stakeholders in quality assurance in higher education. Human Resources Management \& Ergonomics, 11(1), 93-107.

Welzant, H., Schindler, L., Puls-Elvidge, S., \& Crawford, L. (2015). Definitions of quality in higher education: A synthesis of the literature. Higher Learning Research Communications, 5(3), 313. 